\title{
Protective Effect of Lemon Peel Extract on Oxidative Stress in H9c2 Rat Heart Cell Injury
}

\author{
Jun Wang ${ }^{1,2}$ \\ Yulin Zhai ${ }^{1}$ \\ Mingguang $\mathrm{Ou}^{3}$ \\ Yunfeng Bian ${ }^{4}$ \\ Chenglong Tang ${ }^{5}$ \\ Wanchao Zhang ${ }^{6-8}$ \\ Yujiao Cheng ${ }^{1,2}$ \\ Guijie Li (iD) ${ }^{1,2}$
}

'Citrus Research Institute, Southwest University, Chongqing, People's Republic of China; ${ }^{2}$ National Citrus Engineering Research Center, Chongqing, People's Republic of China; ${ }^{3}$ Guang'an Nongfeng Agricultural Development Co., Ltd, Sichuan, People's Republic of China; ${ }^{4}$ Guang'an Zheng Wang Agriculture Co., Ltd, Sichuan, People's Republic of China; ${ }^{5}$ Yuanyang Hongtu Grapefruit Agricultural Technology Development Co., Ltd, Yunnan, People's Republic of China; ${ }^{6}$ Chongqing Institute of Medicinal Plant Cultivation, Chongqing, People's Republic of China; ${ }^{7}$ National Patent Navigation Project (Chongqing) Research and Promotion Center, Chongqing, People's Republic of China; ${ }^{8}$ BioResource Research and Utilization Joint Key Laboratory of Sichuan and Chongqing, Chongqing, People's Republic of China

Correspondence: Wanchao Zhang Tel +86-13072382527

Email boystory@163.com

Guijie Li

I5\# Ganjucun, Xiema, Beibei District, Chongqing, 4007/2, People's Republic of China

Tel +86-17388209637

Email liguijie@cric.cn

\begin{abstract}
Aim: Lemon peel, a traditional Chinese medicine, was tested in this study for its novel application in inhibiting cellular oxidative stress, and the effect of lemon peel extract (LPE) on protecting H9c2 rat heart cells from oxidative stress was investigated.
\end{abstract}

Methods: The scavenging effects of LPE on 1,1-diphenyl-2-picryhydrazyl (DPPH) and 2,2'azino-bis (3-ethylbenzthiazoline-6-sulfonic acid) (ABTS) free radicals were measured in extracellular experiments. The 3-(4,5-dimethyl-2-thiazolinyl)-2,5-diphenyl-2-h-tetrazolylammonium bromide (MTT) assay was used to detect the cell survival rate. The cell supernatant and intracellular oxidation-related indicators were detected by a kit, and the mRNA expression in H9c2 cells was detected by quantitative polymerase chain reaction (qPCR). The chemical substances of LPE were analyzed by high-performance liquid chromatography (HPLC).

Results: The results showed that LPE exhibited better DPPH and ABTS free radical scavenging abilities than vitamin C. Compared with the cells in the normal state (control group), the cell survival rate in the model group decreased, and the level of lactate dehydrogenase (LDH) increased, the levels of superoxide dismutase (SOD), catalase (CAT), and glutathione (GSH) decreased, and the content of malondialdehyde (MDA) increased. Compared with the control group, the expression of Bcl-2-related X protein (Bax), caspase-3, nuclear factor erythroid 2-related factor 2 (Nrf2), and heme oxygenase-1 (HO-1) in the model group was increased, and the expression of B-cell lymphoma-2 (Bcl-2) was reduced. Compared with the model group, LPE treatment improved the cell survival rate, reduced the levels of LDH and MDA, increased the levels of SOD, CAT, and GSH, downregulated the expression of Bax, caspase-3, Nrf2 and HO-1, and upregulated the expression of Bcl-2. The composition analysis showed that LPE contained catechin, rutin, naringin, quercetin, and hesperidin.

Conclusion: The results indicated that LPE could protect $\mathrm{H} 9 \mathrm{c} 2$ cells from oxidative stress through five active components. LPE has the potential to be developed into natural medicine or health food for the inhibition of cell oxidative damage.

Keywords: lemon peel, oxidative stress, H9c2 rat heart cell, mRNA expression, HPLC

\section{Introduction}

As a high-yield crop, lemon is a widely eaten fruit. Lemon is also processed into juice, fruit wine, and other foods. ${ }^{1}$ Lemons are planted in southern China, among which Sichuan Province produces the largest yield of lemons. ${ }^{2}$ Lemon pulp contains fiber, vitamin C, vitamin B, flavonoids, limonin, trace elements, and other active ingredients. ${ }^{3}$ Lemon can also reduce blood sugar, blood lipid levels, and blood pressure. Lemons are also effective in decreasing the harmful effects of cardiovascular diseases, some inflammation, tumors, and other malignant diseases. Each part of the lemon has a good antioxidant effect and shows antiviral effects and 
enhanced immunity. ${ }^{4}$ The juice of a lemon is the primary target of processing. Because the lemon peel is too thick and tough to be widely processed in traditional applications, it is often treated as useless waste in juice production. However, a small part of the peel is used to make traditional Chinese medicine. ${ }^{5}$ Lemon peel also has a variety of chemical compositions, such as abundant flavonoids, ${ }^{3}$ which can be further developed and used for their health benefits.

In the human body, oxidative stress resulting from the imbalance between oxidation and antioxidation causes oxidative damage in the body, causes inflammatory infiltration of neutrophils, and produces various oxidative intermediate harmful products. Oxidative stress produces free radicals in the body that are generally considered to be an important factor in promoting aging and disease. ${ }^{6}$ Oxidative stress can damage cells and impair the oxidative balance. $^{7}$ Oxidative stress plays an important role in pulmonary fibrosis, epilepsy, hypertension, atherosclerosis, Parkinson's disease, and sudden death. ${ }^{8}$ In many disease states, a large number of free radicals produced by oxidative stress are detected in myocardial tissue, leading to myocardial injury. Moreover, oxidative stress may cause apoptosis or necrosis of myocardial cells, resulting in heart disease. ${ }^{9}$ Nuclear factor erythroid 2-related factor 2 (Nrf2) is an oxidative stress regulator that can control antioxidant protein expression, thereby inhibiting oxidative stress. Moreover, the heme oxygenase-1 (HO-1) gene is a Nrf2dependent gene, and its product is a strong antioxidant. Regulation of the Nrf2/HO-1 pathway can reduce oxidative stress. ${ }^{10} \mathrm{H}_{2} \mathrm{O}_{2}$-induced oxidative stress in $\mathrm{H} 9 \mathrm{c} 2$ cells is a mature in vitro cell model used to test the protective effect of active substances on cardiomyocytes. ${ }^{11}$ At the same time, many studies have used this model to test the mechanism by which the Nrf2/HO-1 signaling pathway protects the myocardium. ${ }^{12-15}$ Therefore, the present study used this model to test the effects of LPE and preliminarily verify the mechanism of LPE.

The present study aimed to investigate the in vitro cell protection effects of lemon peel, which can be used as a novel application in traditional Chinese medicine, and to preliminarily explore the underlying mechanism. This manuscript first analyzed the compounds of lemon peels and established evidence of cardiomyocyte damage and in vitro oxidative stress in cell models. To provide a theoretical basis for the better use of lemon peels, the present study observed the inhibitory effect of lemon peel extract (LPE) on oxidative stress-induced damage in cardiomyocytes, analyzed the composition of LPE, and analyzed the mechanism of LPE by activating the Nrf2/ HO-1 signal to inhibit the myocardial protection of oxidative stress.

\section{Materials and Methods LPE Extraction}

The lemons (Eureka lemon; Tongnan, Chongqing, China) were washed, and the pulp was removed to obtain lemon peel slices. Lemon peel samples were freeze-dried, crushed, and passed through a 60-mesh sieve. Lemon peel powder $(50 \mathrm{~g})$ was weighed, combined with $480 \mathrm{~mL}$ of $70 \%$ ethanol $(\mathrm{v} / \mathrm{v})$, and mixed uniformly. The mixture was extracted for $4 \mathrm{~h}$ in a $60^{\circ} \mathrm{C}$ water bath, and the extract was filtered for later use. ${ }^{4}$ After passing evenly through a filter column containing FL-3 macroporous resin (Shanghai Yiji Biology Co., Ltd., Shanghai, China), the filtrate was collected, and the solvent was subjected to rotary evaporation to obtain the LPE. The extracted LPE mainly contained flavonoids and other antioxidant active substances, as the impurities were removed.

\section{Preparation of Standard Solution}

Catechin, rutin, naringin, hesperidin, and quercetin standards were placed in centrifuge tubes, and a methanol solution was added to prepare a standard solution with a concentration of $1.0 \mathrm{mg} / \mathrm{mL}$, which was then passed through a $0.22-\mu \mathrm{m}$ organic filter membrane and placed in a $1.5-\mathrm{mL}$ brown sample bottle for later use.

\section{High-Performance Liquid Chromatographic Detection of LPE Ingredients}

The LPE was diluted 1000 times with methanol and detected under the following chromatographic conditions: Accucore C18 $(4.6 \mathrm{~mm} \times 250 \mathrm{~mm}, 5 \mu \mathrm{m})$ (Agilent, Santa Clara, CA, USA) as the chromatographic column; $0.5 \%$ acetic acid aqueous solution as mobile phase A; acetonitrile solution as mobile phase $\mathrm{B}$; flow rate at $0.5 \mathrm{~mL} / \mathrm{min}$; column temperature at $30^{\circ} \mathrm{C}$; UV-Vis detector; detection wavelength of $285 \mathrm{~nm}$; injection volume of $10 \mu \mathrm{L}$; and 60 min run time. The ingredient contents in the lemon peels were calculated using the external standard method with the following formula: $M_{x}=C_{r} \times A_{x} / A_{r} \times C$, where $M_{x}(m g / g)$ represents the content of the ingredient, $\mathrm{C}_{\mathrm{r}}(\mathrm{mg} / \mathrm{mL})$ represents the mass concentration of the standard product, $\mathrm{Ax}$ represents the measured peak area of the sample, $A_{r}$ 
represents the measured peak area of the standard, and C $(1.0 \mathrm{mg} / \mathrm{mL})$ represents the original concentration of the sample. The linear regression relationships (regression coefficients) of catechin, rutin, naringin, quercetin, and hesperidin standards were $\mathrm{y}=0.0285 \mathrm{x}-0.2828$ $\left(\mathrm{R}^{2}=0.9875\right), \mathrm{y}=0.0348 \mathrm{x}-0.3363\left(\mathrm{R}^{2}=0.9860\right), \mathrm{y}=0.0348 \mathrm{x}-$ $0.3547\left(\mathrm{R}^{2}=0.9889\right), \mathrm{y}=2.0254 \mathrm{x}+0.3644\left(\mathrm{R}^{2}=0.9997\right)$, and $y=1.1892 x-0.6226\left(R^{2}=0.9990\right)$, respectively.

\section{DPPH Free Radical Scavenging Ability Measurement}

DPPH reagent (Solarbio, Beijing, China) was weighed $(0.01 \mathrm{~g})$ and placed in a $250-\mathrm{mL}$ volumetric flask, and absolute ethanol was then added to adjust the concentration of the DPPH solution to $0.1 \mathrm{~mol} / \mathrm{L}$. Different volumes of active LPE ingredients were added separately into the test tube, and ultrapure water was added to a final volume of $0.1 \mathrm{~mL}$. DPPH radical solution $(4.00 \mathrm{~mL}$ of $0.1 \mathrm{~mol} / \mathrm{L})$ was then added, and after shaking well, the solution was set aside for $30 \mathrm{~min}$ in the dark. In place of the sample, absolute ethanol was used for the control. The final reaction solution $(200 \mu \mathrm{L})$ was collected, and the absorbance was measured with a spectrophotometer at a wavelength of $517 \mathrm{~nm} .{ }^{16}$ The measured absorbance value was calculated using the following formula for the scavenging ability of LPE on DPPH free radicals: DPPH clearance rate $(\%)=$ $\left[1-\left(\mathrm{A}_{1}-\mathrm{A}_{2}\right) / \mathrm{A}_{0}\right] \times 100 \%$, where $\mathrm{A}_{0}$ is the absorbance value of absolute ethanol and $4.00 \mathrm{~mL}$ of DPPH blank control, $A_{1}$ is the absorbance value after the reaction of $0.1 \mathrm{~mL}$ of sample solution and $4.00 \mathrm{~mL}$ of $\mathrm{DPPH}$, and $\mathrm{A}_{2}$ is the absorbance value of $0.1 \mathrm{~mL}$ of sample solution and $4.00 \mathrm{~mL}$ of absolute ethanol.

\section{ABTS Free Radical Scavenging Ability Measurement}

Five milliliters of $7 \mathrm{mmol} / \mathrm{mL}$ 2,2'-azino-bis (3-ethylbenzthiazoline-6-sulfonic acid) (ABTS) (Solarbio, Beijing, China) and $88 \mu \mathrm{L}$ of $140 \mathrm{mmol} / \mathrm{mL}$ potassium superphosphate aqueous solution were mixed well and reacted for 12 hours in the dark to keep the free radical ions in a stable state to prepare the ABTS free radical working solution. Different volumes of active ingredient LPEs were added separately into the test tube, and $0.1 \mathrm{~mL}$ of ultrapure water was added. Subsequently, $4.00 \mathrm{~mL}$ of prepared ABTS free radical working solution was added. After shaking well, the mixture reacted at room temperature for $10 \mathrm{~min}$. An equal volume of absolute ethanol was used as a control, and the absorbance was measured at a wavelength of $734 \mathrm{~nm}^{12}$ To determine the scavenging ability of LPE on ABTS free radicals, the measured absorbance value was calculated using the following formula: ABTS clearance rate $(\%)=$ $\left[1-\left(A_{1}-A_{2}\right) / A_{0}\right] \times 100 \%$, where $A_{0}$ is the absorbance value of absolute ethanol and $4.00 \mathrm{~mL}$ of ABTS is the blank control; $\mathrm{A}_{1}$ is $0.1 \mathrm{~mL}$ of sample solution and $4.00 \mathrm{~mL}$ of ABTS after reaction; and $\mathrm{A}_{2}$ is the absorbance value of $0.1 \mathrm{~mL}$ of sample solution and $4.00 \mathrm{~mL}$ of absolute ethanol.

\section{Cell Experiment Grouping}

H9c2 rat cardiomyocytes (Procell Life Science \& Technology Co., Ltd., Wuhan, Hubei, China) grown in the logarithmic phase were divided into five groups as follows: the control group, model $\left(\mathrm{H}_{2} \mathrm{O}_{2}\right.$-induced $)$ group, vitamin $\mathrm{C}(\mathrm{Vc})$ group, low LPE concentration group (LPEL), and high LPE concentration group (LPEH). After resuspension in DMEM containing 10\% fetal bovine serum, H9c2 cells were cultured in a constant-temperature incubator containing $5 \% \mathrm{CO}_{2}$ at $37^{\circ} \mathrm{C}$ for $24 \mathrm{~h}$. Cells grew by adhering to the well (Chen et al). After $24 \mathrm{~h}$, the original culture medium was discarded. A new culture medium was added to the control group to maintain the normal growth of $\mathrm{H} 9 \mathrm{c} 2$ cells, and oxidative damage to H9c2 cells was induced in the model group. After H9c2 cells adhered to the wall, DMEM with a final concentration of $100 \mu \mathrm{mol} / \mathrm{L} \mathrm{H}_{2} \mathrm{O}_{2}$ was added to the culture for $4 \mathrm{~h}$. After H9c2 cells in the Vc group were treated with $\mathrm{H}_{2} \mathrm{O}_{2}$ as the model group, the culture medium was discarded and replaced with culture medium containing $100 \mu \mathrm{mol} / \mathrm{L} \mathrm{Vc}$, and cells were cultured for another 12 hours. After H9c2 cells in the LPEL and LPEH groups were treated with $\mathrm{H}_{2} \mathrm{O}_{2}$ as the model group, the culture medium was discarded and replaced with medium containing $50 \mu \mathrm{mol} / \mathrm{L}$ and $100 \mu \mathrm{mol} / \mathrm{L} \mathrm{LPE}$, respectively, and cells were incubated for another $12 \mathrm{~h}$ (Table 1).

\section{Detecting Cell Viability Using the MTT Method}

After treatment of the cells, $20 \mu \mathrm{L}$ of MTT solution (Thermo Fisher Scientific) was added to the cell culture well at a concentration of $5 \mathrm{~g} / \mathrm{L}$, and cells were placed in the incubator for $4 \mathrm{~h}$. After removing the medium, $150 \mu \mathrm{L}$ of DMSO was added to the treated wells. After shaking, cells were kept in the dark for 20 minutes, and the OD value was measured at a wavelength of $490 \mathrm{~nm}$. The cell survival rate was determined according to the following 
Table I Experimental Grouping and Processing Methods

\begin{tabular}{|c|c|c|c|}
\hline Group & $\begin{array}{c}100 \mu \mathrm{mol} / \mathrm{L} \mathrm{H}_{2} \mathrm{O}_{2} \\
\text { Treatment }(4 \mathrm{~h})\end{array}$ & $\begin{array}{c}\text { Vc } \\
\text { Treatment } \\
(12 \mathrm{~h})\end{array}$ & $\begin{array}{c}\text { LPE } \\
\text { Treatment } \\
(12 \mathrm{~h})\end{array}$ \\
\hline Control & 1 & 1 & 1 \\
\hline Model & $200 \mu \mathrm{L}$ & 1 & I \\
\hline$V_{c}$ & $200 \mu \mathrm{L}$ & $\begin{array}{c}100 \mu \mathrm{mol} / \mathrm{L} \\
200 \mu \mathrm{L}\end{array}$ & I \\
\hline LPEL & $200 \mu \mathrm{L}$ & I & $\begin{array}{c}50 \mu \mathrm{mol} / \mathrm{L} \\
200 \mu \mathrm{L}\end{array}$ \\
\hline LPEH & $200 \mu \mathrm{L}$ & 1 & $\begin{array}{c}100 \mu \mathrm{mol} / \mathrm{L}, \\
200 \mu \mathrm{L}\end{array}$ \\
\hline
\end{tabular}

formula: cell survival rate $(\%)=(\mathrm{OD}$ value of treatment action group/OD value of untreated group) $\times 100 \% .{ }^{17}$

\section{Determining LDH, SOD, MDA, GSH, and CAT Levels in Cells}

After treatment of the cells with the above method, the supernatant and cells were collected. An ultrasonic cell pulverizer was then used to break the cells in an ice water bath. An ultrasound scan was performed once every 3 to 5 seconds for four intervals. The LDH level of the cell supernatant was measured following the manufacturer's instructions of the LDH kit (Table 2), and the absorbance was measured at $450 \mathrm{~nm}$ and was calculated from a standard curve. The SOD, MDA, GSH, and CAT levels in each group of cells were measured with a multifunctional microplate reader (VarioskanLUX, Thermo Fisher Scientific) following the manufacturer's protocols of the SOD, MDA, GSH, and CAT kits (Nanjing Jiancheng Bioengineering Institute, Nanjing, Jiangsu, China). The WST-1 method, ${ }^{18}$ TBA method, ${ }^{19}$ microplate method ${ }^{20}$ and ammonium molybdate method ${ }^{21}$ were used to determine and calculate the absorbance values at $450 \mathrm{~nm}, 532 \mathrm{~nm}, 405 \mathrm{~nm}$, and $405 \mathrm{~nm}$, respectively.

\section{Cell Survival Evaluation}

Cells $\left(5 \times 10^{6}\right)$ were seeded in 6-well plates, cultured for 48 $\mathrm{h}$, and then treated with LPE. The survival status of H9c2 cells was observed under an inverted fluorescence microscope (CKX53, Olympus, Tokyo, Japan) with a calcein AM/PI double staining kit (Solarbio, Beijing, China). The living cells were labeled with green fluorescence, and the dead cells were labeled with red fluorescence.

\section{Quantitative Polymerase Chain Reaction Experiment}

Cells were treated and collected, and an ultrasonic cell pulverizer was used to break the cells in a $4^{\circ} \mathrm{C}$ ice water bath. An ultrasound scan was performed once every 3 to 5 seconds for four intervals. RNA was separated from the cells with TRIzol $^{\mathrm{TM}}$ (Solarbio, Beijing, China) and diluted to $1 \mu \mathrm{g} / \mu \mathrm{L}$. Diluted RNA $(1 \mu \mathrm{L})$ was used to obtain cDNA via reverse transcription according to the reverse transcription kit. cDNA template $(1 \mu \mathrm{L})$ was mixed with $10 \mu \mathrm{L}$ of SYBR Green PCR Master Mix (Thermo Fisher Scientific), $1 \mu \mathrm{L}$ of each primer of

Table 2 Determination Steps of LDH Kit

\begin{tabular}{|c|c|c|c|c|}
\hline Treatment & Blank & Standard & Text & Control \\
\hline Double distilled water $(\mu \mathrm{L})$ & 25 & 5 & & \\
\hline $0.2 \mu \mathrm{mol} / \mathrm{mL}$ pyruvate standard solution $(\mu \mathrm{L})$ & & 20 & & \\
\hline Tested sample $(\mu \mathrm{L})$ & & & 20 & 20 \\
\hline Matrix buffer $(\mu \mathrm{L})$ & 25 & 25 & 25 & 25 \\
\hline Coenzyme I $(\mu \mathrm{L})$ & & & 5 & \\
\hline \multicolumn{5}{|l|}{ Mix well and take a $37^{\circ} \mathrm{C}$ water bath for $15 \mathrm{~min}$} \\
\hline 2,4-dinitrophenylhydrazine $(\mu \mathrm{L})$ & 25 & 25 & 25 & 25 \\
\hline \multicolumn{5}{|l|}{ Mix well and take a $37^{\circ} \mathrm{C}$ water bath for $15 \mathrm{~min}$} \\
\hline $0.4 \mathrm{~mol} / \mathrm{L} \mathrm{NaOH}$ solution $(\mu \mathrm{L})$ & 250 & 250 & 250 & 250 \\
\hline
\end{tabular}


Table 3 qPCR Primer Sequences

\begin{tabular}{|l|l|}
\hline Gene & \multicolumn{1}{c|}{ Primer Sequence } \\
\hline Bcl-2 & $\begin{array}{l}\text { F: 5'-ATGTGTGTGGAGAGCGTCAACC-3' } \\
\text { R: 5'-CAGAGACAGCCAGGAGAAATCAA-3' }\end{array}$ \\
\hline Bax & $\begin{array}{l}\text { F: 5'-CCCGAGAGGTCTTTTTCCGAG-3' } \\
\text { R: 5'-CCAGCCCATGATGGTTCTGAT-3' }\end{array}$ \\
\hline Caspase-3 & F: 5'-CATGGAAGCGAATCAATGGACT-3' \\
& R: 5'-CTGTACCAGACCGAGATGTCA-3' \\
\hline HO-I & F: 5'-ATTGCCTGTAAGTCCTGGTCA-3' \\
& R: 5'-ACTGCTCTTTGGACATCATTTCG-3' \\
\hline GAPDH & F: 5'-AACTTTCAGAAGGGCCAGGT-3' \\
& R: 5'-CTGGGCTCTCCTTGTTGC-3' \\
\hline
\end{tabular}

forward primers and reverse primers (Table 3; Solarbio, Beijing, China), and $7 \mu \mathrm{L}$ of sterilized distilled water. The following thermocycler program was used: $95^{\circ} \mathrm{C}$ for $60 \mathrm{~s}$; and 40 cycles of $95^{\circ} \mathrm{C}$ for $15 \mathrm{~s}, 55^{\circ} \mathrm{C}$ for $30 \mathrm{~s}, 72^{\circ} \mathrm{C}$ for $35 \mathrm{~s}, 95^{\circ} \mathrm{C}$ for $30 \mathrm{~s}$ and $55^{\circ} \mathrm{C}$ for $35 \mathrm{~s}$ (Stepone Plus, Thermo Fisher Scientific). The expression intensity relative to the control group was calculated using the $2^{-\Delta \Delta} \mathrm{Ct}$ method, and the GAPDH housekeeping reference gene was used for normalization. ${ }^{22}$

\section{Statistical Analysis}

Three parallel experiments were performed to obtain the average value, which was determined using SPSS 23 statistical software and compared between groups using independent-sample $t$ tests and a one-way analysis of variance

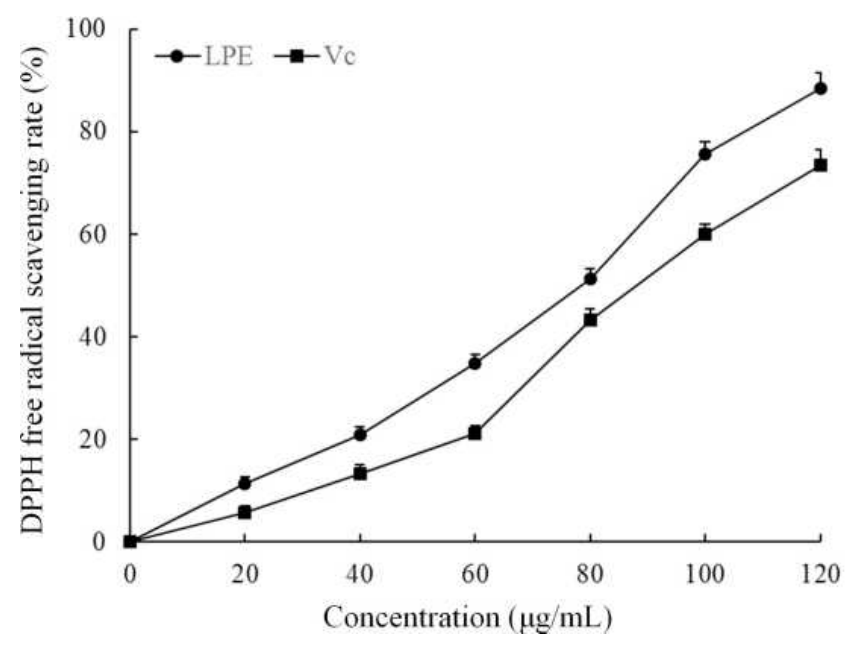

Figure I Scavenging activity of lemon peel extract on DPPH and ABTS free radicals. method. Significant differences between groups were observed at the $P<0.05$ level.

\section{Results DPPH and ABTS Radical Scavenging Abilities of LPE}

Figure 1 shows the dose-response relationship of DPPH and the ABTS radical scavenging ability of LPE. The ability of LPE to scavenge DPPH and ABTS radicals increased with increasing concentrations of LPE from 0 to $120 \mu \mathrm{g} / \mathrm{mL}$. Moreover, the Vc positive control group had lower DPPH and ABTS radical scavenging abilities than LPE.

\section{Viability of H9c2 Cells with Oxidative Damage Induced by LPE Treatment}

The survival rate of the $\mathrm{H} 9 \mathrm{c} 2$ cell model group was lower than that of the control group, and the difference was statistically significant (Figure 2, $P<0.05$ ). Compared with the model group, the survival rate of $\mathrm{H} 9 \mathrm{c} 2$ cells with oxidative damage treated with $\mathrm{VC}$ and LPE was increased $(P<0.05)$, and the effect of LPE was dose-dependent. The effect of LPE on the survival rate of $\mathrm{H} 9 \mathrm{c} 2$ cells with oxidative damage was stronger than that of $\mathrm{Vc}$ at the same concentration.

\section{LDH Level in the Supernatant of LPE-Treated H9c2 Cells with Oxidative Damage}

The control group had a lower level of LDH (118.36 \pm $8.32 \mathrm{U} / \mathrm{L}$ ) than the other groups, while the model group had a higher level of LDH $(539.47 \pm 20.36 \mathrm{U} / \mathrm{L})$ than the other groups (Figure 3). LPE reduced the LDH level of

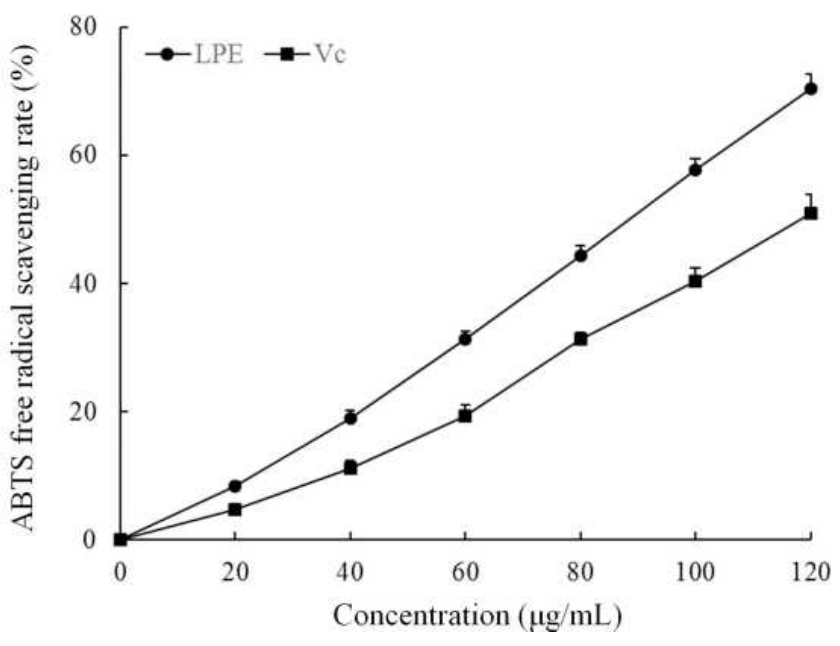




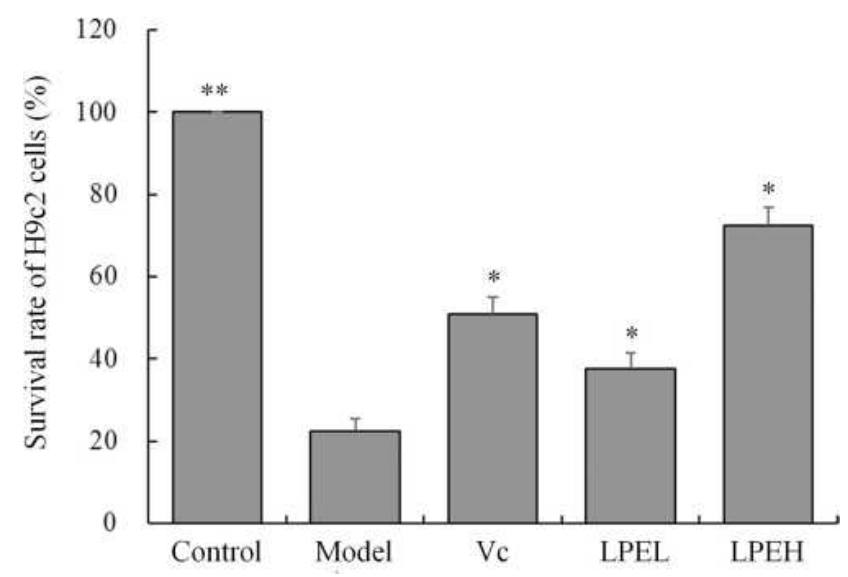

Figure 2 Effect of lemon peel on the survival rate of H9c2 cells with oxidative damage. *There was a significant difference between the experience group and the model group at the level of $P<0.05$. **There was a significant difference between the experience group and the model group at the level of $P<0.01$. Control: untreated $\mathrm{H} 9 \mathrm{c} 2$ cells; model: $\mathrm{H}_{2} \mathrm{O}_{2}$-treated $\mathrm{H} 9 \mathrm{c} 2$ cells; $\mathrm{Vc}_{\mathrm{c}} \mathrm{H}_{2} \mathrm{O}_{2}$ and $100 \mu \mathrm{mol} / \mathrm{L}$ vitamin C-treated H9c2 cells; LPEL: $\mathrm{H}_{2} \mathrm{O}_{2}$ - and $50 \mu \mathrm{mol} / \mathrm{L}$ LPE-treated $\mathrm{H} 9 \mathrm{c} 2$ cells; LPEL: $\mathrm{H}_{2} \mathrm{O}_{2}$ - and $100 \mu \mathrm{mol} / \mathrm{L}$ LPE-treated $\mathrm{H} 9 \mathrm{c} 2$ cells.

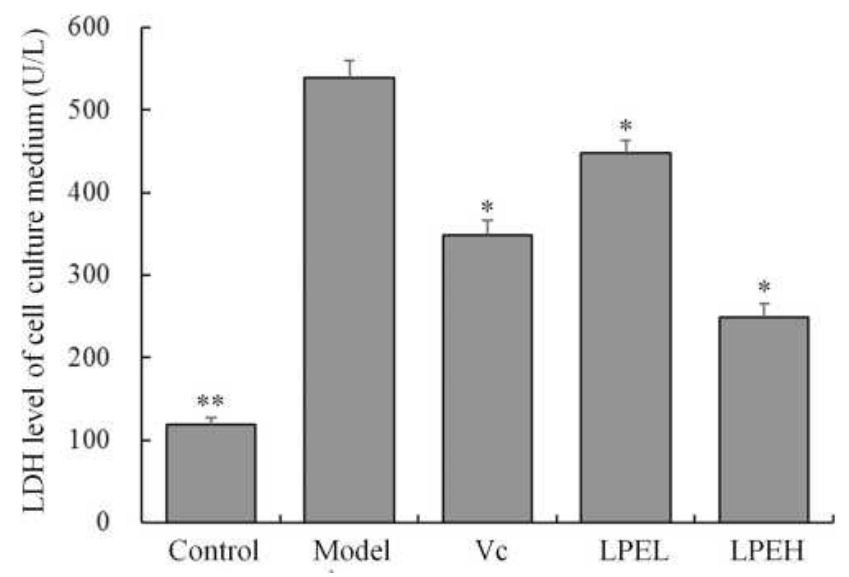

Figure 3 Effect of lemon peel on LDH levels in H9c2 cells with oxidative damage. *There was a significant difference between the experience group and the model group at the level of $P<0.05$. **There was a significant difference between the experience group and the model group at the level of $P<0.01$. Control: untreated H9c2 cells; model: $\mathrm{H}_{2} \mathrm{O}_{2}$-treated $\mathrm{H} 9 \mathrm{c} 2$ cells; $\mathrm{Vc}$ : $\mathrm{H}_{2} \mathrm{O}_{2}$ - and $100 \mu \mathrm{mol} / \mathrm{L}$ vitamin C-treated H9c2 cells; LPEL: $\mathrm{H}_{2} \mathrm{O}_{2}$ - and $50 \mu \mathrm{mol} / \mathrm{L}$ LPE-treated H9c2 cells; LPEL: $\mathrm{H}_{2} \mathrm{O}_{2}$ - and $100 \mu \mathrm{mol} / \mathrm{L}$ LPE-treated $\mathrm{H} 9 \mathrm{c} 2$ cells.

cells with oxidative damage. Higher concentrations of LPE resulted in lower LDH levels. The effect of LPE on the LDH level was better than that of the VC antioxidant.

\section{SOD, MDA, GSH, and CAT Levels of LPE-Treated H9c2 Cells with Oxidative Damage}

The SOD, GSH, and CAT levels of H9c2 cells with oxidative damage (model group) were lower than those of the other groups, but the MDA level was higher than that of
Table 4 Effect of Lemon Peel Extract on SOD, MDA, GSH and CAT Levels of $\mathrm{H} 9 \mathrm{c} 2$ Cells with Oxidative Injury

\begin{tabular}{|l|c|c|c|c|}
\hline Group & $\begin{array}{c}\text { SOD (U/ } \\
\text { gprot) }\end{array}$ & $\begin{array}{c}\text { MDA (nmol/ } \\
\text { gprot) }\end{array}$ & $\begin{array}{c}\text { GSH } \\
(\boldsymbol{\mu m o l} / \\
\mathbf{m g})\end{array}$ & $\begin{array}{c}\text { CAT (U/ } \\
\text { gprot) }\end{array}$ \\
\hline Control & $\begin{array}{c}191.36 \\
\pm 10.83^{* *}\end{array}$ & $0.80 \pm 0.05^{* *}$ & $\begin{array}{c}65.69 \\
\pm 4.36^{* *}\end{array}$ & $\begin{array}{c}155.30 \\
\pm 12.69 * *\end{array}$ \\
\hline Model & $52.05 \pm 4.99$ & $7.02 \pm 0.42$ & $21.52 \pm 3.25$ & $\begin{array}{c}41.03 \\
\pm 4.09\end{array}$ \\
\hline Vc & 117.62 & $3.89 \pm 0.29 *$ & 40.82 & 90.36 \\
$\pm 8.01^{* *}$ & & $\pm 3.75^{*}$ & $\pm 6.32^{*}$ \\
\hline LPEL & 90.83 & $5.11 \pm 0.34^{*}$ & 31.02 & 63.25 \\
$\pm 6.12^{*}$ & & $\pm 2.79 *$ & $\pm 5.29 *$ \\
\hline LPEH & 151.08 & $1.44 \pm 0.27^{* *}$ & 53.06 & 121.36 \\
& $\pm 10.20^{* *}$ & & $\pm 3.86^{* *}$ & $\pm 7.33^{* *}$ \\
\hline
\end{tabular}

Notes: *There was a significant difference between the experience group and the model group at the level of $P<0.05$. **There was a significant difference between the experience group and the model group at the level of $P<0.01$. Control: untreated $\mathrm{H} 9 \mathrm{c} 2$ cells; model: $\mathrm{H}_{2} \mathrm{O}_{2}$-treated $\mathrm{H} 9 \mathrm{c} 2$ cells; $\mathrm{Vc}_{\mathrm{c}} \mathrm{H}_{2} \mathrm{O}_{2}$ - and $100 \mu \mathrm{mol} / \mathrm{L}$ vitamin C-treated H9c2 cells; LPEL: $\mathrm{H}_{2} \mathrm{O}_{2-}$ and $50 \mu \mathrm{mol} / \mathrm{L}$ LPE-treated $\mathrm{H} 9 \mathrm{c} 2$ cells; LPEL: $\mathrm{H}_{2} \mathrm{O}_{2}$ - and $100 \mu \mathrm{mol} / \mathrm{L}$ LPE-treated $\mathrm{H} 9 \mathrm{c} 2$ cells.

the other groups $(P<0.05$, Table 4$)$. After treatment with LPE and Vc, the SOD, GSH, and CAT levels of H9c2 cells with oxidative damage were increased, but the MDA level was reduced. In addition, these levels in the LPEH group were the most similar to those in the control group.

\section{H9c2 Cell Survival Status}

As shown in Figure 4, the H9c2 cell survival status was observed under an inverted fluorescence microscope. The numerous control H9c2 cells were full, polygonal, and abundantly cytoplasmic with a large number of viable cells visualized by fluorescent staining. H9c2 cells in the model group appeared shrunken and decreased in number with cell damage and cell death. LPE was able to inhibit $\mathrm{H}_{2} \mathrm{O}_{2}$ induced $\mathrm{H} 9 \mathrm{c} 2$ cell damage and death. The number of $\mathrm{H} 9 \mathrm{c} 2$ cells increased with an increasing concentration of LPE, and cell damage and death were alleviated. Thus, these findings demonstrate that LPE could effectively inhibit $\mathrm{H} 9 \mathrm{c} 2$ cell damage and cell number reduction caused by $\mathrm{H}_{2} \mathrm{O}_{2}$, indicating that LPE plays a role in protecting cells.

\section{Bcl-2, Bax, Caspase-3, Nrf2, and HO-I mRNA Expression in LPE-Treated H9c2 Cells with Oxidative Damage}

The control H9c2 cells had lower Bax, caspase-3, Nrf2, and HO-1 mRNA expression but higher Bcl-2 expression 


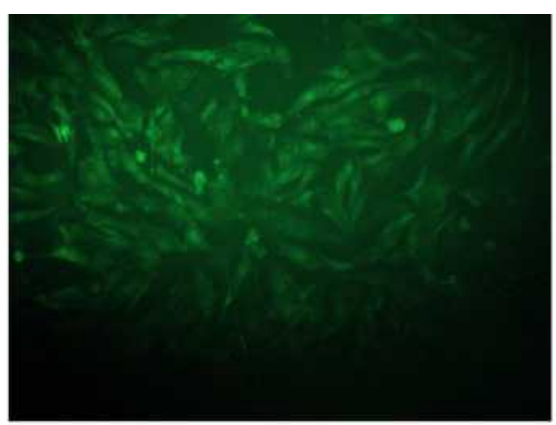

Control

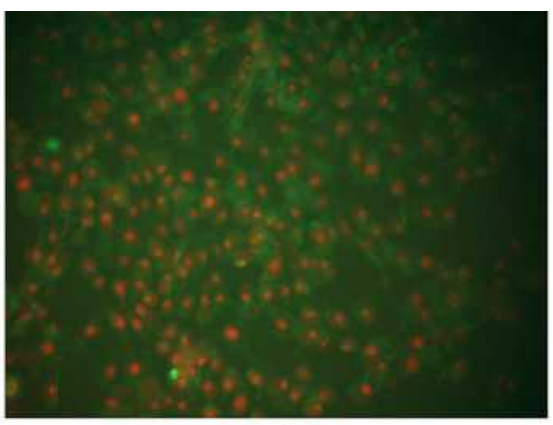

Model

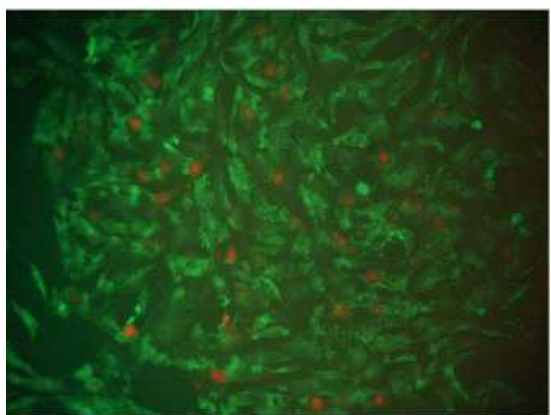

$\mathrm{Vc}$

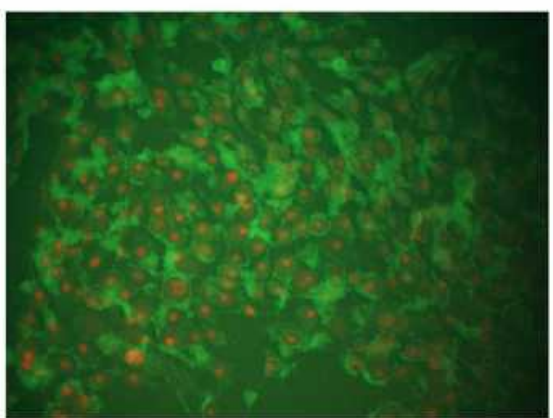

LPEL

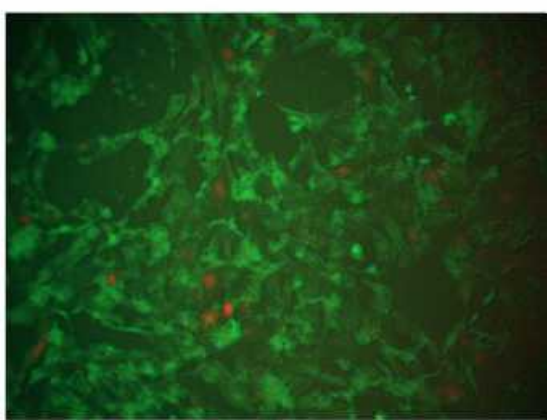

LPEH

Figure 4 Effects of lemon peel on the survival of $\mathrm{H} 9 \mathrm{c} 2$ cells $(200 \times)$. Living cells were labeled with green fluorescence, and dead cells were labeled with red fluorescence. Control: untreated $\mathrm{H} 9 \mathrm{c} 2$ cells; model: $\mathrm{H}_{2} \mathrm{O}_{2}$-treated $\mathrm{H} 9 \mathrm{c} 2$ cells; $\mathrm{Vc}$ : $\mathrm{H}_{2} \mathrm{O}_{2}$ - and $100 \mu \mathrm{mol} / \mathrm{L}$ vitamin C-treated $\mathrm{H} 9 \mathrm{c} 2$ cells; $\mathrm{LPEL}$ : $\mathrm{H}_{2} \mathrm{O}{ }_{2}$ and $50 \mu \mathrm{mol} / \mathrm{L}$ LPE-treated H9c2 cells; LPEL: $\mathrm{H}_{2} \mathrm{O}_{2}$ and $100 \mu \mathrm{mol} / \mathrm{L}$ LPE-treated $\mathrm{H} 9 \mathrm{c} 2$ cells.

than the other groups. Moreover, the model group H9c2 cells had higher Bax, caspase-3, Nrf2, and HO-1 expression but lower Bcl-2 expression than the other groups (Figure 5). Vc, LPEL and LPEH increased Bcl-2 expression but decreased Bax, caspase-3, Nrf2, and HO-1 expression in $\mathrm{H} 9 \mathrm{c} 2$ cells with oxidative damage (model group), and the effects of LPEH were stronger than those of LPEL and Vc.

\section{Chemical Composition of LPE}

According to the chemical composition measurements in the experiments, the most important active ingredients in the peels of lemons produced in Yueyang, Sichuan were catechin, rutin, naringin, quercetin, and hesperidin (Figure 6) with contents of $206.54 \mathrm{mg} / \mathrm{g}, 44.60 \mathrm{mg} / \mathrm{g}, 5.68 \mathrm{mg} / \mathrm{g}$, $187.75 \mathrm{mg} / \mathrm{g}$, and $25.11 \mathrm{mg} / \mathrm{g}$, respectively. Importantly, these five components all have good antioxidant effects. These results indicate that the most important active substances were catechin and quercetin.

\section{Discussion}

DPPH and ABTS are commonly used to detect the antioxidant activity of active substances. ${ }^{16,17}$ In this study,
LPE had good DPPH and ABTS scavenging abilities in extracellular experiments, suggesting that LPE may have a strong antioxidant effect.

Although early thrombolysis, percutaneous coronary intervention, and coronary artery bypass grafting have reduced the mortality of acute myocardial infarction, acute myocardial infarction is still the main cause of death and disability worldwide. After acute myocardial infarction, patients inevitably experience left ventricular remodeling mediated by oxidative stress and cardiomyocyte apoptosis. Inhibition of oxidative stress and cardiomyocyte apoptosis might reduce the degree of remodeling after acute myocardial infarction. ${ }^{23,24}$ The essence of oxidative damage is the massive production of ROS, which exceeds the self-clearing ability, resulting in damage to lysosomes and mitochondria. ${ }^{25} \mathrm{H}_{2} \mathrm{O}_{2}$ is an oxidative metabolite in the human body, and it reacts with free iron ions in the nucleus and generates more reactive oxygen radicals, leading to cell damage, which in turn induces apoptosis and ultimately cell death. ${ }^{26}$ The present study confirmed that $\mathrm{H}_{2} \mathrm{O}_{2}$ can reduce the survival rate of $\mathrm{H} 9 \mathrm{c} 2$ cells and that $\mathrm{LPE}$ can protect 

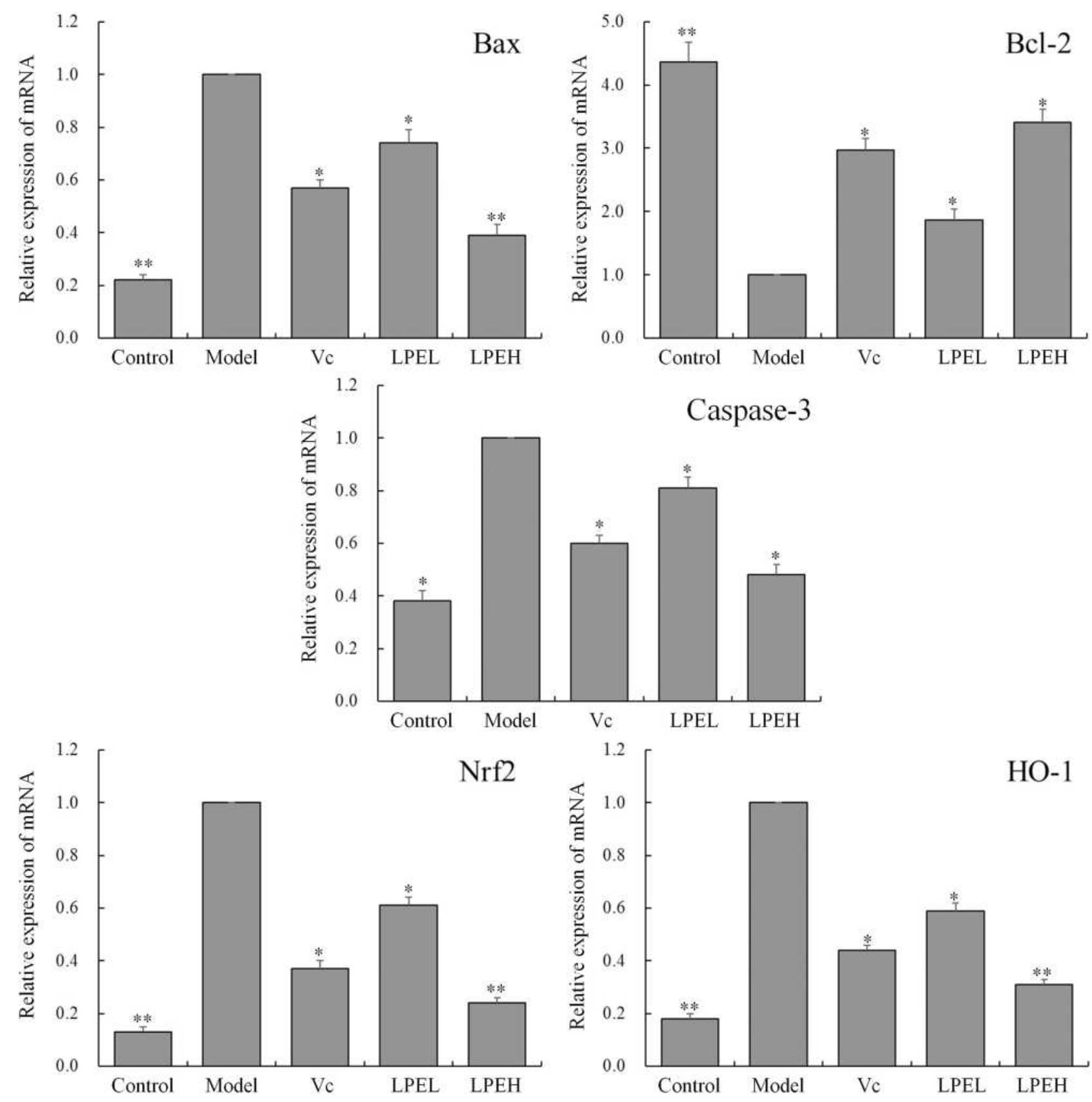

Figure 5 Effects of lemon peel on Bcl-2, Bax, Caspase-3, Nrf2, and HO-I mRNA expression. *There was a significant difference between the experience group and the model group at the level of $P<0.05$. **There was a significant difference between the experience group and the model group at the level of $P<0.0 \mathrm{I}$. Control: untreated $\mathrm{H} 9 \mathrm{c} 2$ cells; model: $\mathrm{H}_{2} \mathrm{O}_{2}$-treated $\mathrm{H} 9 \mathrm{c} 2$ cells; $\mathrm{Vc}_{\mathrm{c}} \mathrm{H}_{2} \mathrm{O}_{2-}$ and $100 \mu$ mol/L vitamin C-treated $\mathrm{H} 9 \mathrm{c} 2$ cells; LPEL: $\mathrm{H}_{2} \mathrm{O}_{2-}$ and $50 \mu$ mol/L LPE-treated H9c2 cells; LPEL: $\mathrm{H}_{2} \mathrm{O}_{2-}$ and $100 \mu \mathrm{mol} / \mathrm{L}$ LPE-treated $\mathrm{H} 9 \mathrm{c} 2$ cells.

against $\mathrm{H}_{2} \mathrm{O}_{2}$-induced oxidative damage in $\mathrm{H} 9 \mathrm{c} 2$ cells as indicated by an increased survival rate.

When the body is under normal conditions, serum and body fluids have low levels of LDH, but a large amount of $\mathrm{LDH}$ in the cells is released after the cell membrane is damaged. ${ }^{27}$ LDH can damage and inhibit damaged and repaired cells. SOD, as the main endogenous antioxidant, can also reduce mitochondrial damage and maintain cell stability by scavenging excessive oxygen free radicals. ${ }^{28}$ GSH and CAT are also important antioxidant enzymes in vivo. Under oxidative stress, these enzymes play the role of strong antioxidants, reduce the cell and tissue damage caused by oxidative damage, and repair the abnormalities caused by oxidative damage. ${ }^{29}$ MDA is 

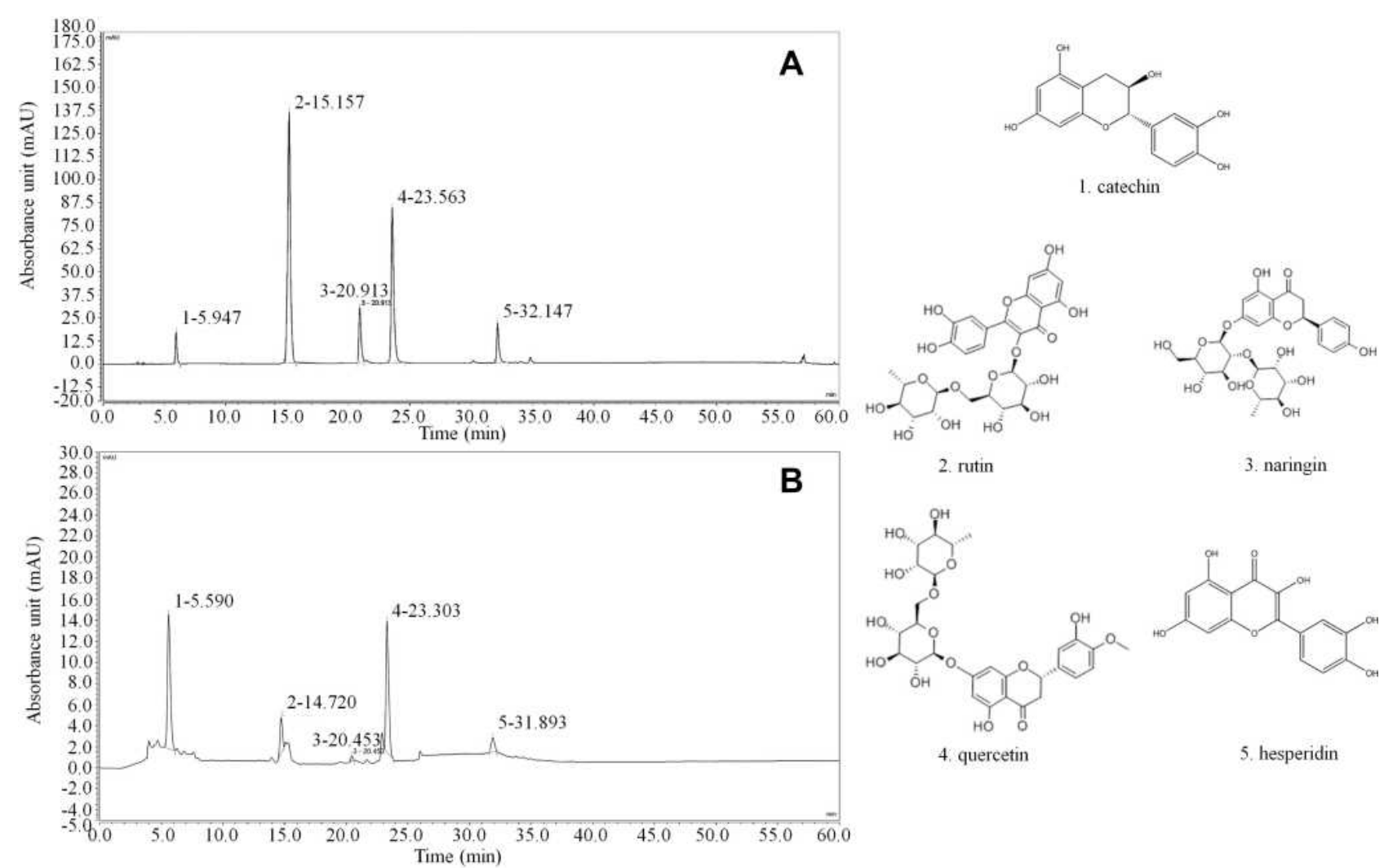

Figure 6 Chemicals of lemon peel extract. (A) Standard chromatograms. (B) Lemon peel extract chromatograms.

representative of a series of oxidative damage products, and a large amount of MDA strengthens the degree of oxidative damage. ${ }^{30}$ This study also showed that LPE can regulate the $\mathrm{LDH}, \mathrm{SOD}, \mathrm{MDA}, \mathrm{GSH}$, and CAT levels in oxidatively damaged cardiomyocytes, thereby protecting cells and inhibiting oxidative damage.

Apoptosis is a common form of programmed cell death in the body. ${ }^{31}$ The main mechanism of myocardial cell death is metabolism, and Bax and Bcl-2 are involved in this process. The degree of cell necrosis and death is determined by the ability of the membrane to adjust. ${ }^{32}$ The caspase family plays an important role in cell death. When Bax binds to the membrane, the concentration of the ions between the inner and outer membrane changes, leading to cytochrome $\mathrm{C}$ release into the cell, cleavage of caspase-9, and activation of Caspase-3, resulting in cell death. ${ }^{33}$ The qPCR results showed that LPE increased Bcl2 mRNA expression but decreased Bax and Caspase-3 mRNA expression, indicating that LPE might protect myocardial cells by suppressing myocardial infarction.

$\mathrm{Nrf2}$, as a factor that regulates stress, could suppress stress, and its level is adjusted by HO- $1 .{ }^{34}$ Normally, Nrf2 and Keap1 are in nonactive forms in cells. After damage,
$\mathrm{Nrf} 2$ is quickly separated from Keap1 and enters the nuclear core, where it plays a protective role through regulating downstream genes and the expression of HO$1 .{ }^{35}$ At the same time, research has shown that Nrf2 can also regulate the expression of $\mathrm{Bcl}-2$, SOD, and CAT, which have antiaging effects. ${ }^{36} \mathrm{Nrf} 2$, as a central transcription factor of the endogenous antioxidant pathway, can regulate the expression of antioxidants and Phase II enzymes, and it can be one of the targets of cardiac protection. $\mathrm{H}_{2} \mathrm{O}_{2}$-treated cardiomyocytes could induce the expression of $\mathrm{Nrf2}$ and its downstream genes, thereby protecting the cells against adriamycin-induced apoptosis. Adenovirus-mediated $\mathrm{Nrf} 2$ gene transfection increases the expression of NQO1 in cardiomyocytes. ${ }^{37,38}$ After $\mathrm{H}_{2} \mathrm{O}_{2}$ treatment, cardiomyocytes regulate antioxidants to inhibit oxidative stress, and as oxidative stress is inhibited, Nrf2 expression decreases. ${ }^{39}$ qPCR also found that LPE had an anti-inflammatory effect by increasing the mRNA levels of Nrf2 and HO-1. This result suggested that the anti-inflammatory effect of BCP might be related to the Nrf2/HO-1 signaling pathway.

Some experiments have confirmed that catechin, rutin, naringin, and quercetin have protective effects on the heart 
and cardiomyocytes. ${ }^{40-42}$ Catechin has a strong antioxidant effect and plays a variety of roles, such as antiviral and fungicidal activities as well as the prevention of various types of inflammation. ${ }^{43}$ Rutin can be used as a food antioxidant and nutrition enhancer, but it also has antiinflammatory effects and can play a role in protecting the skin. At the same time, because of its strong antioxidant activity, rutin can inhibit the formation of lipid peroxides. $^{44}$ Naringin is also a strong antioxidant with anti-inflammatory, antiviral, anticancer, antimutation, antiallergy, antiulcer, analgesic, and antihypertensive activities. Naringin can lower blood cholesterol, reduce thrombosis, improve local microcirculation, and improve nutrition supply, and it can be used in the prevention and treatment of cardiovascular and cerebrovascular diseases. ${ }^{45}$ Quercetin can resist complex or capture free radicals and prevent lipid peroxidation. In addition, quercetin can reduce blood pressure, enhance capillary resistance, reduce capillary fragility, lower blood lipids, expand coronary arteries, and increase coronary blood flow. Quercetin also has adjuvant treatment effects on patients with coronary heart disease and hypertension. ${ }^{46}$ Hesperidin has good antioxidant, anti-inflammatory, and antibacterial effects. Hesperidin can also increase venous tension and protect the cardiovascular system by prolonging the time of noradrenalin-induced venous contraction. ${ }^{47}$ Thus, these findings suggest that the protective effect of LPE on cardiomyocytes is mainly derived from the antioxidant capacity, cardiovascular protection, and regulatory effects of these components.

\section{Conclusion}

In summary, LPE had a protective effect on damaged $\mathrm{H} 9 \mathrm{c} 2$ cells, and the effect of high-concentration LPE (LPEH) was better than that of low-concentration LPE (LPEL), which showed that the effect of LPE was positively correlated with the concentration. The mechanism might be related to the five active substances in LPE, which may regulate the signaling pathway of Nrf2/HO1 , to increase the activity of SOD, GSH, CAT, and other anti-inflammatory components in myocardial cells to prevent cell death. The purpose of this study was to elucidate the chemical mechanism of LPE and clarify the targeting effect of LPE to provide a theoretical basis for the further development and use of lemon peel. However, the present study was limited to in vitro experiments. Because in vivo animal experiments would more accurately show the effect and mechanism of LPE, future research will strengthen the results of the present study.

\section{Acknowledgments}

This research was funded by The National Key Research and Development Program of China (2017YFD0400701); Fundamental Research Funds for the Central Universities (XDJK2020C026); Southwest University campus cooperation (Research and development of planting and processing technology of high quality lemon in Nongfeng agriculture; Construction of Zheng Wang agricultural high-quality Orchard and Research and development of its supporting technology; Construction of standardized Green Pomelo Orchard in Yuanyang County, Yunnan; and Grant Number 2020001040).

\section{Disclosure}

Mr Wanchao Zhang reports grants from Ministry of Science and Technology, during the conduct of the study. The authors report no other conflicts of interest in this work.

\section{References}

1. Penniston KL, Nakada SY, Holmes RP, et al. Quantitative assessment of citric acid in lemon juice, lime juice, and commercially-available fruit juice products. J Endourol. 2008;22(3):567-570. doi:10.1089/ end.2007.0304

2. Li YL, Liu LP, Tong LY, et al. Effect of inulin on the quality of low sugar low fat yogurt. Food Ferment Ind. 2015;41(12):131-134. doi:10.13995/j.cnki.11-1802/ts.201512024

3. Zhang JW, Tan L, Zhang YZ, et al. Debittering of lemon juice using surface molecularly imprinted polymers and the utilization of limonin. J Chromatogr B. 2019;1104:205-211. doi:10.1016/j. jchromb.2018.11.025

4. Tag HM, Kelany OE, Tantawy HM, et al. Potential anti-inflammatory effect of lemon and hot pepper extracts on adjuvant-induced arthritis in mice. J Basic Appl Zool. 2014;67(5):149-157. doi:10.1016/j. jobaz.2014.01.003

5. Lai QH, Wang XL, Wang CQ, et al. Current processing and utilization situation of fruit peels and research progress. J Food Safety Qual. 2017;8(3):876-881. doi:10.3969/j.issn.2095-0381.2017.03.024

6. Chen ZH, Zhang GE, Wei ZX, et al. Effects of jiangtang xiaozhi granules on vascular endothelial function in type 2 diabetes patients with qi-yin deficiency and phlegm-stasis inter-obstruction syndrome. Chin J Integr Tradit Western Med. 2018;38(5):544-548. doi:10.7661/ j.cjim.20180417.156

7. He QH, Li YC, Wang WJ, et al. Intervention function of astaxanthin from haematococcus pluvialis on brain injury diabetic rats. J Chin Inst Food Sci Technol. 2019;19(5):33-38. doi:10.16429/j.10097848.2019.05.005

8. Siti HN, Kamisah Y, Kamsiah J. The role of oxidative stress, antioxidants and vascular inflammation in cardiovascular disease (a review). Vascul Pharmacol. 2015;71:40-56. doi:10.1016/j. vph.2015.03.005

9. Song XL, Qian LJ, Li FZ. Effect of cold stress on injury of rat cardiomyocyte. J Prev Med Chin People's Liberat Army. 2001;19 (2):88-91. doi:10.3969/j.issn.1001-5248.2001.02.003 
10. Foresti R, Bains SK, Pitchumony TS, et al. Small molecule activators of the Nrf2-HO-1 antioxidant axis modulate heme metabolism and inflammation in BV2 microglia cells. Pharmacol Res. 2013;76:132-148. doi:10.1016/j.phrs.2013.07.010

11. Tang YZ, Liu ZQ. Free-radical-scavenging effect of carbazole derivatives on DPPH and ABTS radicals. J Am Oil Chem Soc. 2007;84 (12):1095-1100. doi:10.1007/s11746-007-1149-y.

12. Zhang J, Wang H, Yi S, et al. Protective effect of insect tea primary leaf (Malus sieboldii (Regal) Rehd.) extract on $\mathrm{H}_{2} \mathrm{O}_{2}$-induced oxidative damage in human embryonic kidney $293 \mathrm{~T}$ cells. Appl Biol Chem. 2020;63(1):32. doi:10.1186/s13765-020-00516-y

13. Zhou JY, Prognon P. Raw material enzymatic activity determination: a specific case for validation and comparison of analytical methodsthe example of superoxide dismutase (SOD). J Pharm Biomed Anal. 2006;40(5):1143-1148. doi:10.1016/j.jpba.2005.09.022.

14. Schmedes A, Holmer G. A new thiobarbituric acid (TBA) method for determining free malondialdehyde (MDA) and hydroperoxides selectively as a measure of lipid peroxidation. $J$ Am Oil Chem Soc. 1989;66(6):813-817. doi:10.1007/bf02653674

15. Rahman I, Kode A, Biswas SK. Assay for quantitative determination of glutathione and glutathione disulfide levels using enzymatic recycling method. Nat Protoc. 2006;1(6):3159-3165. doi:10.1038/ nprot.2006.378

16. Hadwan MH, Abed HN. Data supporting the spectrophotometric method for the estimation of catalase activity. Data Brief. 2015;6:194-199. doi:10.1016/j.dib.2015.12.012

17. Mu JF, Tan F, Zhou XR, et al. Lactobacillus fermentum CQPC06 in naturally fermented pickles prevents non-alcoholic fatty liver disease by stabilizing the gut-liver axis in mice. Food Funct. 2020;11 (10):8707. doi:10.1039/D0FO01823F

18. Zhou MM, Zhang WY, Li RJ, et al. Anti-inflammatory activity of Khayandirobilide A from Khaya senegalensis via NF- $\kappa \mathrm{B}, \mathrm{AP}-1$ and p38 MAPK/Nrf2/HO-1 signaling pathways in lipopolysaccharide-stimulated RAW 264.7 and BV-2 cells. Phytomedicine. 2018;42:152-163. doi:10.1016/j.phymed.2018.03.016

19. Bagatini MD, Martins CC, Battisti V, et al. Oxidative stress versus antioxidant defenses in patients with acute myocardial infarction. Heart Vessels. 2011;26(1):55-63. doi:10.1007/s00380-010-0029-9.

20. Finck BN, Han XL, Courtois $M$, et al. A critical role for PPARalpha-mediated lipotoxicity in the pathogenesis of diabetic cardiomyopathy: modulation by dietary fat content. Proc Nat Acad Sci USA. 2013;100(3):1131-1226. doi:10.1073/pnas.0336724100

21. Peng $\mathrm{ZH}$. Protective effect and mechanism of reduced glutathione on severe acute pancreatitis with liver function lesion. Mod J Integr Tradit Chin Western Med. 2015;2015(8):805-807. doi:10.3969/j. issn.1008-8849.2015.08.003

22. Hwang SL, Yen G. Neuroprotective effects of the citrus flavanones against $\mathrm{H}_{2} \mathrm{O}_{2}$-induced cytotoxicity in PC12 cells. J Agri Food Chem. 2008;56(3):859-964. doi:10.1021/jf072826r

23. Li QM, Qu WL, Chen BJ. Effect and mechanism of dendrobii officinalis caulis in intervening and preventing myocardial fibrosis in rats with heart failure and heart qi deficiency syndrome after ischemia-reperfusion. Chin J Exp Tradit Med Formulae. 2019;25 (15):83-88. doi:10.13422/j.cnki.syfjx.20191502

24. Wu Z, You F, Wang Y, et al. Effects of waterborne Fe(II) on micronucleus and nucleus anomaly of erythrocyte and activities of AKP and SOD in juvenile turbot (Scophthalmus maximus). Transact Oceanol Limnol. 2011;2011(4):45-51. doi:10.3969/j.issn.10036482.2011 .04 .007

25. Liu X, Liu H, Zhai Y. Laminarin protects against hydrogen peroxide-induced oxidative damage in MRC-5 cells possibly via regulating NRF2. PeerJ. 2017;5:e3642. doi:10.7717/peerj.3642
26. Mcnamara CR, Ahuja R, Osafo-Addo AD, et al. Akt regulates TNF $\alpha$ synthesis downstream of RIP1 kinase activation during necroptosis. PLoS One. 2013;8(3):e56576. doi:10.1371/journal.pone.0056576

27. Li J, Shang T, Kong G, et al. Study on cell apoptosis in the placenta of preeclampsia. Reproduct Contracept. 2005;25(9):531-537. doi:10.3969/j.issn.0253-357X.2005.09.004

28. Li YX, Li XW, Nong XL. Review on anti-tumor mechanism and clinical application of artesunate. Nat Prod Res Deve. 2016;28 (6):986-989. doi:10.16333/j.1001-6880.2016.6.028

29. Yu AJ, Tan SY. The relationship between curcumin and non-alcoholic fatty liver disease. Chin $J$ Gastroenterol Hepatol. 2017;26 (10):1107-1109. doi:10.3969/j.issn.1006-5709.2017.10.009

30. Kang HJ, Hong YB, Kim HJ, et al. CR6-interacting factor 1 (CRIF1) regulates NF-E2-related factor 2 (NRF2) protein stability by proteasome-mediated degradation. J Biol Chem. 2010;285 (28):21258-21268. doi:10.1074/jbc.M109.084590

31. Rosa PB, Bettio LEB, Neis VB, et al. The antidepressant-like effect of guanosine is dependent on GSK-3 $\beta$ inhibition and activation of MAPK/ ERK and Nrf2/heme oxygenase-1 signaling pathways. Purinergic Signal. 2019;15(4):491-504. doi:10.1007/s11302-019-09681-2

32. Purdom-Dickinson SE, Lin Y, Dedek M, et al. Induction of antioxidant and detoxification response by oxidants in cardiomyocytes: evidence from gene expression profiling and activation of Nrf2 transcription factor. $J$ Mol Cell Cardiol. 2007;42(1):159-176. doi:10.1016/j.yjmcc.2006.09.012

33. Cao Z, Zhu H, Zhang L, et al. Antioxidants and Phase 2 enzymes in cardiomyocytes: chemical inducibility and chemoprotection against oxidant and simulated ischemia-reperfusion injury. Exp Biol Med. 2006;231(8):1353-1364. doi:10.1109/8.662660

34. He HB, Shi MQ, Luo T, et al. Total saponin from rhizoma panacis majoris protects neonatal rat cardiomyocytes against oxidative stress-induced injuries by improving Nrf2 translocation. Acta Acad Med Mil Tertiae. 2012;34(15):1527-1532.

35. Tong HM. Detection of oxidation resisting activity and content of flavonoid in different ChenPi with HPLC. Gansu J Tradit Chin Med. 2012;25(7):17-19. doi:10.3969/j.issn.1004-6852.2012.07.007

36. Ye JX, Wang L, Liang RX, et al. Protection and its mechanism of catechin morphon on hypoxia-reoxynation induced injury in myocardial cells. China J Chin Mat Med. 2008;33(7):801-805. doi:10.3321/ j.issn:1001-5302.2008.07.020

37. Zuo GY, Yang CX, Ruan ZJ, et al. Potent anti-MRSA activity and synergism with aminoglycosides by flavonoid derivatives from the root barks of Morus alba, a traditional Chinese medicine. Med Chem Res. 2019;28(9):1547-1556. doi:10.1007/s00044-019-02393-7

38. Tang S, Sheehan D, Buckley DJ, et al. Anti-oxidant activity of added tea catechins on lipid oxidation of raw minced red meat, poultry and fish muscle. Int $J$ Food Sci Technol. 2001;36(6):685-692. doi:10.1046/j.1365-2621.2001.00497.x

39. Sharma SK, Krishna Murti CR. The anti-oxidant action of rutin on tissue peroxidization and release of lysosomal acid phosphatase. Biochem Pharmacol. 1966;15(12):2025-2029. doi:10.1016/00062952(66)90230-9

40. Yang Y, Gong W, Jin C, et al. Naringin ameliorates experimental diabetic renal fibrosis by inhibiting the ERK1/2 and JNK MAPK signaling pathways. J Funct Foods. 2018;50:53-62. doi:10.1016/j.jff.2018.09.020

41. Sohn EJ, Kim JM, Kang SH, et al. Restoring effects of natural anti-oxidant quercetin on cellular senescent human dermal fibroblasts. Am J Chin Med. 2018;46(4):853-873. doi:10.1142/ s0192415x18500453

42. Kumar A, Chaudhary T, Mishra J. Minocycline modulates neuroprotective effect of hesperidin against quinolinic acid induced Huntington's disease like symptoms in rats: behavioral, biochemical, cellular and histological evidences. Eur J Pharmacol. 2013;720(1-3):16-28. doi:10.1016/j.ejphar.2013.10.057 


\section{Publish your work in this journal}

Drug Design, Development and Therapy is an international, peerreviewed open-access journal that spans the spectrum of drug design and development through to clinical applications. Clinical outcomes, patient safety, and programs for the development and effective, safe, and sustained use of medicines are a feature of the journal, which has also been accepted for indexing on PubMed Central. The manuscript management system is completely online and includes a very quick and fair peer-review system, which is all easy to use. Visit http://www. dovepress.com/testimonials.php to read real quotes from published authors. 